\title{
Modelling floodplain inundation for environmental flows: Gwydir wetlands, Australia
}

\author{
S.J. Powell ${ }^{a, *}$, R.A. Letcher ${ }^{a, b}$, B.F.W. Croke ${ }^{a, b}$ \\ a The Fenner School of Environment and Society, The Australian National University, Canberra, ACT 0200, Australia \\ b Department of Mathematics, The Australian National University, Canberra, ACT 0200, Australia
}

\section{A R T I C L E I N F O}

Article history:

Received 1 June 2006

Received in revised form

10 September 2007

Accepted 21 September 2007

Published on line 8 November 2007

\section{Keywords:}

Wetland model

Water balance

Wetlands

Floodplains

Water management

Remote sensing

Decision support

Terminal floodplain

\begin{abstract}
A B S T R A C T
Floodplain wetlands rely on catchment flows to maintain the flooding cycles critical to their ecological integrity. The development of water resources has significantly altered the flow patterns in many river systems. Recent research into water requirements for wetland systems shows that duration, frequency, depth, timing and extent of flooding are the most important influences on ecological communities. Modelling these systems is hampered by a lack of data and inappropriate model structures. Remote sensing using AVHRR satellite data were shown to be an effective option for assessing flood dynamics. Vegetation communities and flood patterns of the Gwydir floodplain were analysed to provide a model structure based on channel, flowpath and core wetland components. The temporal and spatial behaviour of each component was described using water balance principles. The model was calibrated and tested under a range of climatic conditions and the results demonstrate that the model can simulate ecologically significant flood dynamics of the floodplain wetland. This study demonstrates that a conceptually based, semi-distributed water balance approach can provide the basis for an effective decision support system for water management.
\end{abstract}

(c) 2007 Elsevier B.V. All rights reserved.

\section{Introduction}

Floodplain wetlands rely on inflows from catchments to maintain the flooding and drying cycles critical to their ecological integrity. In inland Australia, these wetland systems can be permanent, semi-permanent or ephemeral and may link to downstream river systems or become terminal inland deltas. Many of these wetlands have national and international significance to a range of vegetation and bird communities (Allan and Lovett, 1997; Environment Australia, 2001). The development of water resources has significantly altered the flow patterns in many river systems (Chauhan and Gopal, 2005; Kingsford, 2000; Sanchez-Carrillo et al., 2004). Management is essential because of the impact of river regulatory structures that control most of the flow. Community and government pressure has seen a change in water management practices towards more equitable and sustainable sharing of water resources between the environment and water users. In order for this change to be effective the water requirements of the environment need to be understood. This paper proposes a parsimonious semi-distributed water balance model of ecologically significant flood dynamics. The key criteria required as outputs of the model over identified ecological communities include the depth and duration of flooding, the area inundated by a flood event, and the soil moisture balance for floodplains and wetlands to assess drying and parching.

Current approaches to water resource planning include the use of decision support systems, with an emphasis on testing

\footnotetext{
* Corresponding author. Tel.: +61 261252706.

E-mail address: sue.powell@anu.edu.au (S.J. Powell). 0304-3800/\$ - see front matter @ 2007 Elsevier B.V. All rights reserved. doi:10.1016/j.ecolmodel.2007.09.013
} 
water management scenarios (Letcher et al., 2004; Podger and Hameed, 2000; Simons et al., 1996; Young et al., 2003). These decision support systems can provide an estimate of daily flow into a floodplain or wetland system from a range of scenarios. To subsequently test these scenarios against a range of ecological benefit or response over large scale floodplain wetland systems is more difficult. Recent research into water requirements for floodplain vegetation (Brock and Casanova, 1997; Casanova and Brock, 2000; Mawhinney, 2003; Roberts and Marston, 2000; Roberts et al., 2000) has shown that the duration and frequency of flooding, as well as pre-existing community structure, are the most important influences on plant community composition. Inflow volumes, water depth, timing of flows, the extent of flooding and the flooding cycles in other wetlands have been shown to influence the number of colonial waterbirds nesting (Kingsford and Auld, 2005; Kingsford and Johnson, 1998). A model that simulates the impact of inflows on the frequency and duration of flooding as well as the depth and area inundated is required.

Complex hydraulic and one-, two- and three-dimensional models, based on the differential equations of hydrodynamics, are routinely used to model flood flows over floodplains for floodplain development and asset protection (Department of Infrastructure Planning and Natural Resources, 2004; Thompson et al., 2004; Whigham and Young, 2001). These models require large amounts of data and are generally applied to assess floodplain development impacts at a design flood level. Another common approach to modelling floodplain water requirements is the use of water balance equations (Bennett and McCosker, 1994; Ferrati and Canziani, 2005; Keyte, 1994; Young et al., 2003). Simple daily massbalance water budget models including inflows, outflows, precipitation, evapotranspiration and groundwater seepage have also been used to model constructed through-flow wetlands (Zhang and Mitsch, 2005) and integrated into grid-based models in low-gradient dryland rivers (Costelloe et al., 2003). In the Murray River, Australia, the Murray Flow Assessment Tool (MFAT) (Young et al., 2003) and the Flood Inundation Model (Overton, 2005) have been developed with more spatial and temporal representation of flood dynamics and have linked the flood dynamics to ecological response in the form of habitat preference curves. These often take the form of an empirical relationship between water depth, length of inundation and plant response. The application of the models and estimates in their current forms are limited in terminal floodplain wetland systems. This is mainly due to the lack of soil moisture accounting within the model structure, and the paucity of traditional calibration data as there are no downstream outlet points to calibrate against.

Spatial modelling using remote sensing to map and classify wetlands, and to estimate flood extent (Costelloe et al., 2003; Faulkenmire, 2004; Kingsford and Thomas, 2002; McCarthy et al., 2003) is also used in floodplain wetland assessment and is of value in determining flood patterns and dynamics. Roberts et al. (2000) suggest building volume-area relationships to describe hydrologic patterns in floodplain wetlands using data from remote sensing. This type of spatial approach must still be coupled with temporal modelling to enable testing of flow management scenarios against ecologically significant flood dynamics.
The papers outlined above have focussed on the assessment of free surface water (flooding) at a range of temporal and spatial scales. In inland Australia antecedent conditions impact on flood duration and extent and the inclusion of soil moisture status into a floodplain model is critical to assess the benefit to a range of vegetation types. The aim of this study was to assess the use of remote sensing to provide spatial and temporal analysis of flood dynamics and soil moisture status and to apply the results to the development of a semidistributed daily water balance model relevant to ecological water management in a terminal wetland system.

\section{Study area}

The Gwydir wetlands are located in the Gwydir catchment, part of the Murray-Darling Basin in northwest NSW (Fig. 1). With a catchment area of $25900 \mathrm{~km}^{2}$ (Department of Environment and Conservation, 2003), the Gwydir River flows from the New England Plateau in the east to the Barwon River at Collarenebri in the west. The major tributaries join the Gwydir River upstream of Moree, while downstream the river forms an inland delta across vast floodplains. The floodplain and wetland complex is located on private grazing and cropping properties and experiences highly irregular flooding regimes. In all but the largest floods, inflows are retained within the wetlands and do not contribute to flows in the Barwon River. In 1993, 102000 ha of the Gwydir Wetlands were listed in the Directory of Important Wetlands and in 1999, 823 ha of privately owned farming properties were designated as Wetlands of International Importance under the Ramsar Convention (Environment Australia, 2001). The listings were in recognition of the ecological significance of the wetlands as waterbird habitat (Allan and Lovett, 1997; Environment Australia, 2001).

The river divides into two floodplains composed of floodplain vegetation communities (Fig. 1). The more frequently flooded areas contain core wetland water meadows comprising Paspalum distichum (water couch) and Bulboschoenus fluviatilis (marsh clubrush) in association with a range of wetland flora (Mawhinney, 2003; McCosker, 1994). The core wetlands also include Muehlenbeckia florulenta (lignum) and Acacia stenophylla (river cooba) association which provide the nesting habitat of colonial nesting birds. Eucalyptus camaldulensis (river red gum) is associated with the larger channels and the Gwydir raft on the eastern margin of the floodplain, while E. coolabah (coolabah) associations dominate the less frequently flooded clay soils of the broader floodplains (Keyte, 1994). Vegetation mapping (McCosker, 1994) and ongoing monitoring of the core wetland area response have been undertaken (Chessman and Jones, 2001; Chessman, 2003; Mawhinney, 2003; McCosker, 1996, 1999, 2001a,b).

Moree is located on the eastern fringe of the floodplains and has a mean annual rainfall of $585 \mathrm{~mm}$ (Bureau of Meteorology, 2004). The rainfall decreases from east to west, with mean annual rainfall in the headwaters of the Gwydir catchment in excess of $750 \mathrm{~mm}$, while at the junction of the Mehi River and Barwon rivers to the west, rainfall is less than $450 \mathrm{~mm}$ (Keyte, 1994). Two climatic systems produce flood-generating 


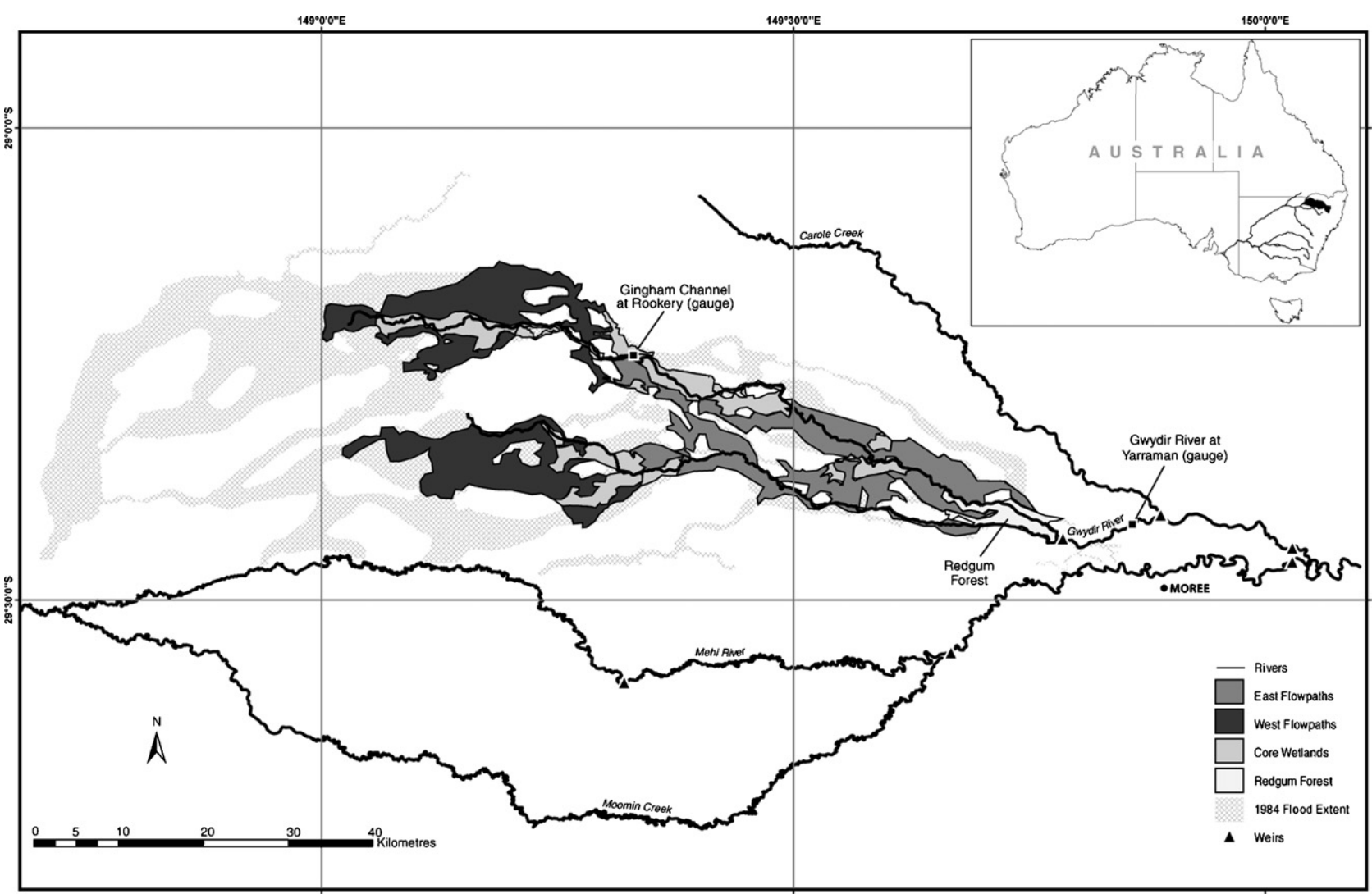

Fig. 1 - Location of study site in NW NSW, Australia. Spatial arrangements of system components including flowpaths, core wetlands and frequently flooded redgum forest used in the model prototype. Also shown is the 1984 flood extent.

rainfall events. Summer storms are dominated by tropical low-pressure systems and monsoonal troughs approaching from the northwest, decaying into inland rain depressions. Winter storms occur when cold fronts from the south or southwest pass over warmer, moisture laden low-pressure systems from the northwest, triggering substantial rainfall events. During summer, the region also experiences high intensity, short duration convectional thunderstorms that can produce heavy localised rainfall and local flooding (Keyte, 1994).

\section{Data acquisition}

\subsection{Flood events}

Floods in the Gwydir catchment since 1977 have been characterized using observed daily inflows (Fig. 2) from the Gwydir River at Yarraman gauge (Fig. 1). Flows greater than $10000 \mathrm{ML}$ will generally cause overland flooding into the core wetland areas, while a flow between 5000 and $10000 \mathrm{ML} /$ day may provide some flooding depending on upstream extractions and the antecedant conditions. Flows between 1000 and $5000 \mathrm{ML} /$ day may also replenish low lying areas adjacent to the channels or may increase the duration of an existing flood. The largest flood through this period occurred in July 1998 with a peak daily flow of over $112000 \mathrm{ML}$ and a total volume over 87 days of $823000 \mathrm{ML}$. The longest period between floods with peak daily inflows greater than $10000 \mathrm{ML}$ was 1440 days, pre- ceding a small flood in 1995. In summary, floods are highly variable in frequency, size and seasonality (Fig. 2).

This paper follows a distinct flood event commencing in 2004 to evaluate the use of remote sensing in data acquisition and model development. This sequence, running for 43 days from 1 December 2004 included a short, pre-flood lead-in time and two flood peaks measured at the Gwydir River at Yarraman gauge. Rainfall and pan evaporation daily records for Moree were obtained for the flood event from the Bureau of Meteorology website (2004) (Fig. 3). For model evaluation and testing, the Gingham Channel at Rookery gauge is used. This height gauge is located within core wetland areas representing the transition between a water meadow and the lignum associations (Fig. 1) where colonial bird nesting occurs.

\subsection{Methods}

Monitoring and mapping of wetlands using satellite imagery has been undertaken over a range of temporal and spatial scales (Barton and Bathols, 1989; Kingsford and Thomas, 2002; McCarthy, 2002; McCarthy et al., 2005, 2003; Mertes, 2002; Mohamed et al., 2004; Phinn, 1998; Roshier and Rumbachs, 2004; Sheng et al., 2001; Smith, 1997; Verdin, 1996). The application of visible/infrared satellite data to map open water bodies can be considered routine, providing vegetation or cloud cover does not obscure the water surface (Smith, 1997). 


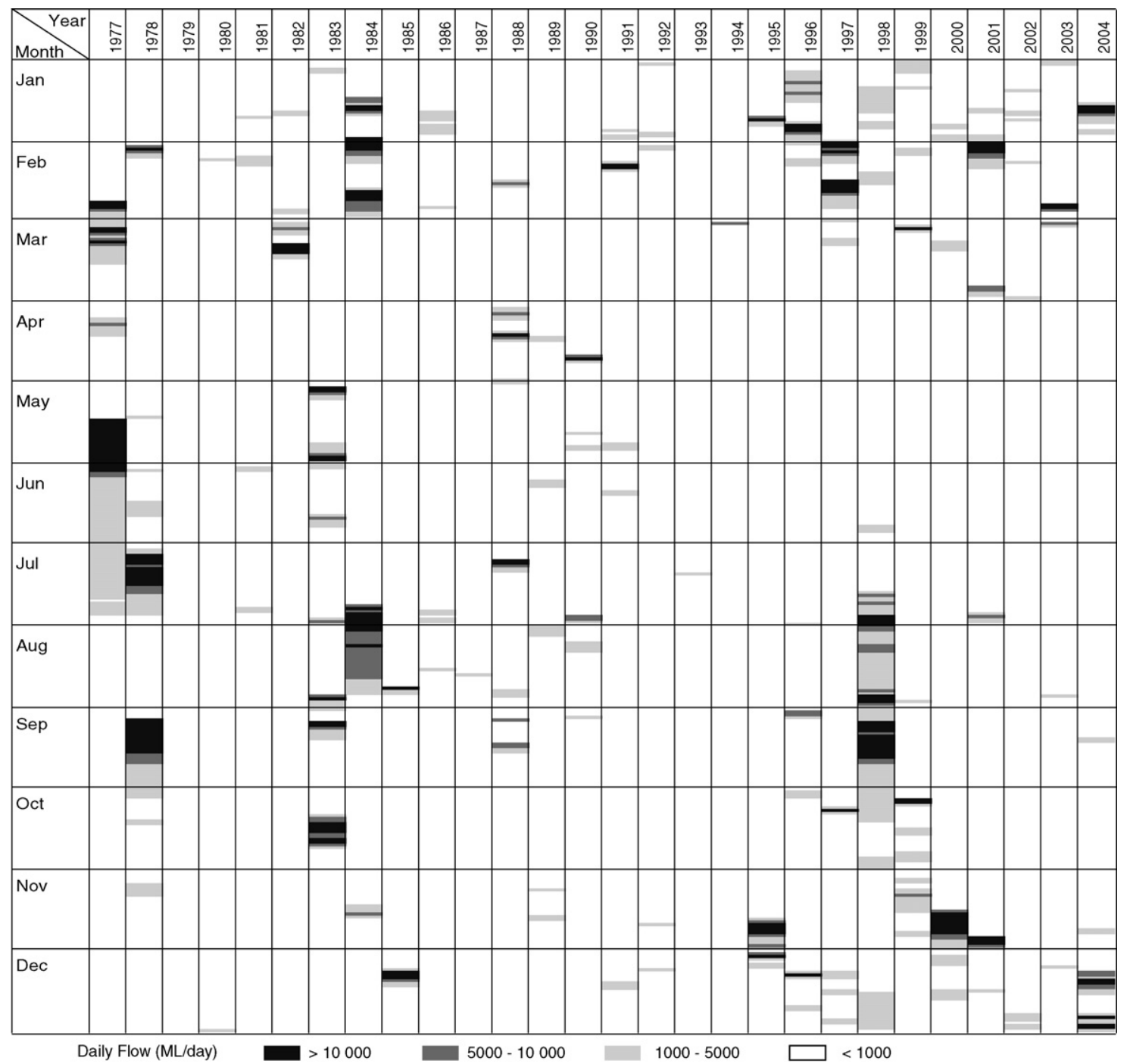

Fig. 2 - Daily inflow volumes to the Gwydir wetlands showing flood events greater than $10000 \mathrm{ML} /$ day (black), 5000-10000 ML/day (dark-grey), and 1000-5000 ML/day (light-grey).

Based on Mertes (2002) overview of the spatial and temporal resolution of various remote sensing instruments used in flood monitoring, and the availability and cost of satellite data, NOAA AVHRR (Advanced Very High Resolution Radiometer) data were used to define the flood dynamics. Data were accessed via the Geoscience Australia, ACRES (Australian Centre for Remote Sensing) website (Geoscience Australia, 2005) during the test flood with daily images available within $24 \mathrm{~h}$ of satellite passes. The datasets are map oriented, georeferenced and radiometrically calibrated using the CAPS

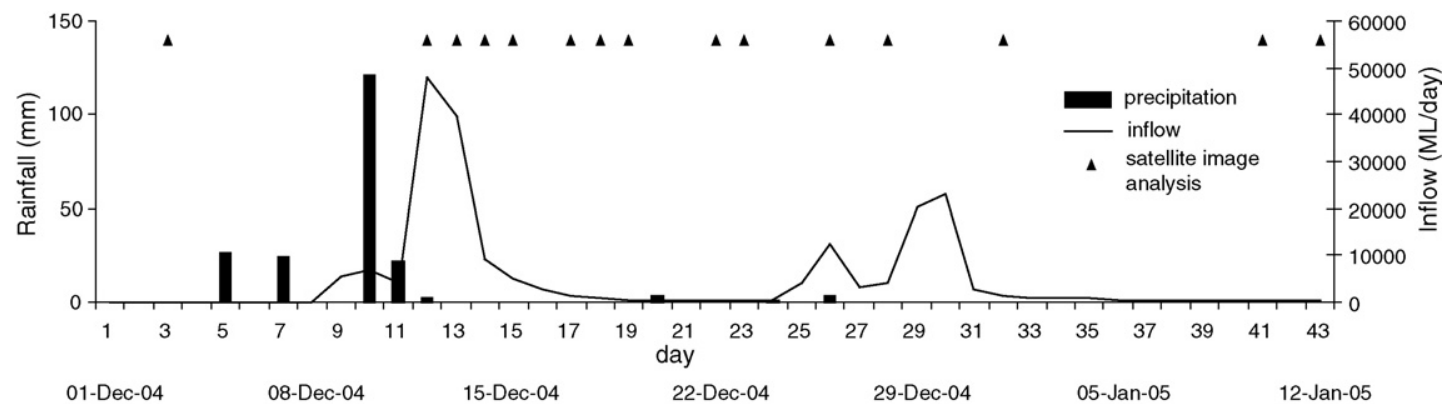

Fig. 3 - Daily rainfall at Moree and inflows at Gwydir River at Yarraman December 2004-January 2005. Triangles show the dates when AVHRR images were analysed. Source: Australian Bureau of Meteorology website, accessed 13 January 2005 , NSW Department of Infrastructure, Planning and Natural Resources surface water data archive accessed 29 April 2005. 
(a) Number

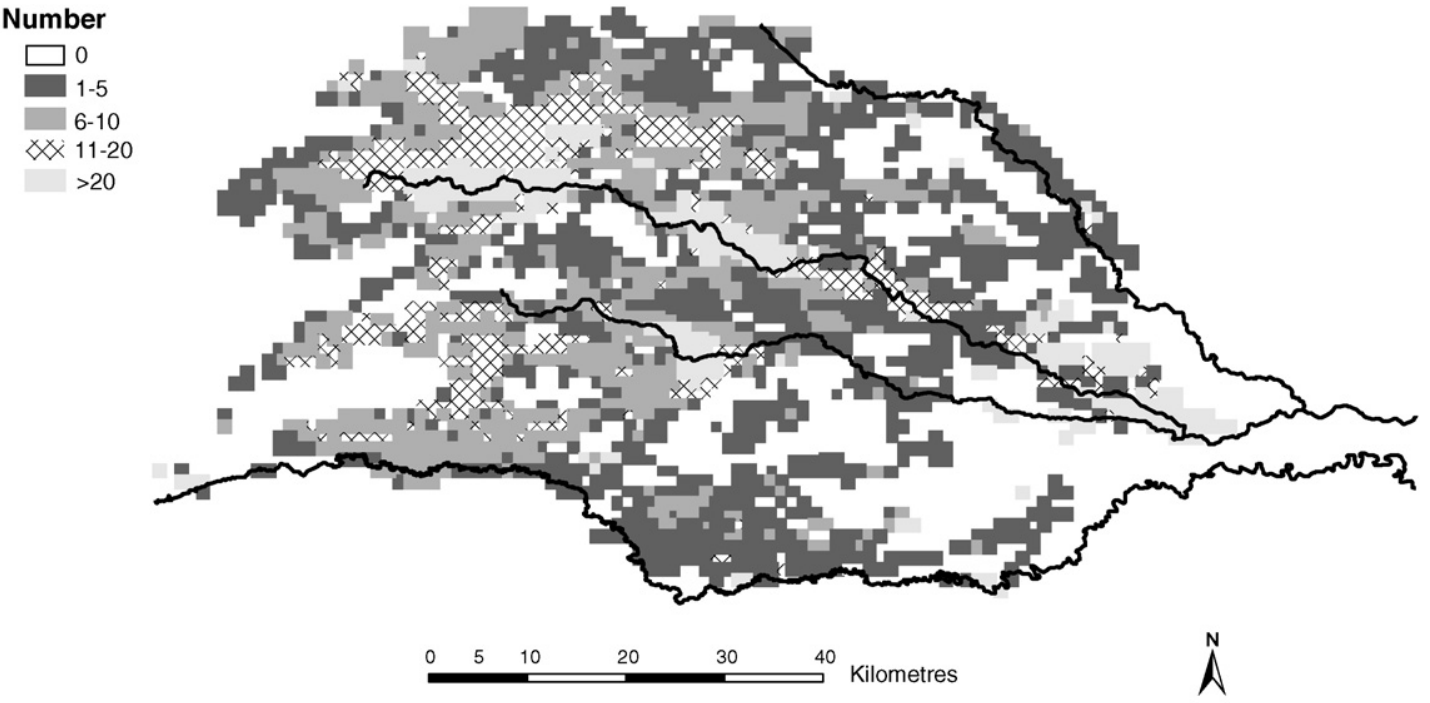

(b) First day wet

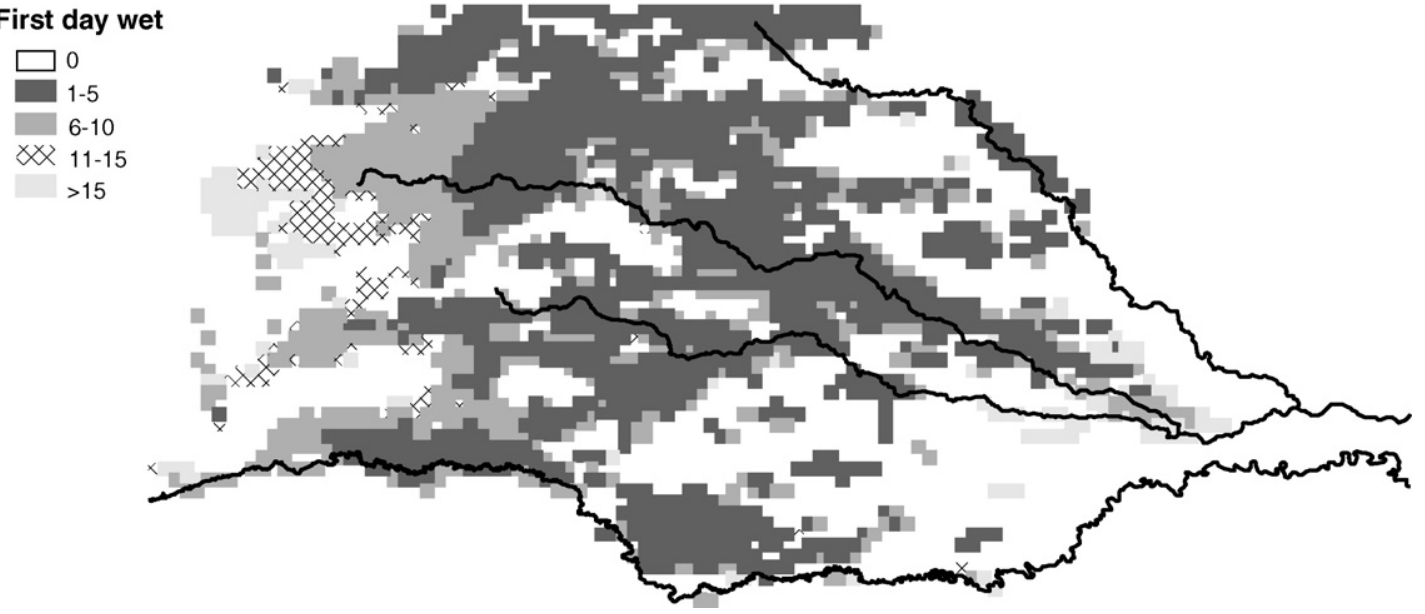

Fig. 4 - Raster grid of (a) number of days with open surface water and (b) the number of days taken for the flood front to reach each pixel. Emergent wetland vegetation may mask the open water signal after 7-21 days depending on the growth response to flooding of the species.

(Common AVHRR Processing Software) (Turner and Davies, 1998) Version 2.5. Images were downloaded and examined for cloud cover. Those images with heavy cloud cover over the region of interest were discarded. Bands 1, 2 and 3a (visible, near and middle infrared, respectively) for the remaining datasets (the satellite image analysis dates are shown in Fig. 4) were converted to percent reflectance using metadata specifications.

A number of spectral bandwidths may be used to determine flood extent. Sheng et al. (2001) suggested that the AVHRR channel band 2 (from 0.725 to $1.00 \mu \mathrm{m}$ ) was the most effective single band to distinguish land from water. Differential and ratio models of bands 1 and 2 have also been shown to be effective while the brightness temperature derived from band 4 and/or band 5 can be effective using either nighttime or daytime images under some circumstances (Barton and Bathols, 1989; Verdin, 1996). Density slicing of the midinfrared band of Landsat TM data (band 5) has also shown to be effective in delineating water bodies on riverine floodplains (Frazier and Page, 2000) and corresponds to band 3a on the most recent AVHRR instrument. Ground-truthing was limited to visual comparison with oblique aerial photographs and observations of local landowners.

Using the results of the density slicing of AVHRR band 3a, raster cells are recoded as wet/dry according to the day since the flood peak. Wet cells were recoded to an integer representing the day since the flood peak (days wet), while dry cells were recoded 0 . A raster math approach was then used to determine the day when first flooded to provide an indication of flood front travel time, and the number of days that were continuously wet for each cell.

\subsection{Results}

Of all the AVHRR channels, the reflectance for the AVHRR/3 band $3 a(1.58-1.64 \mu \mathrm{m})$ over the period of the flood showed the best differentiation between clearly wet pixels and dry pixels for each of the images, although there are some differences in dry pixel reflectance between dates. Density slicing at $11 \%$ reflectance of the single band was effective in distinguishing 


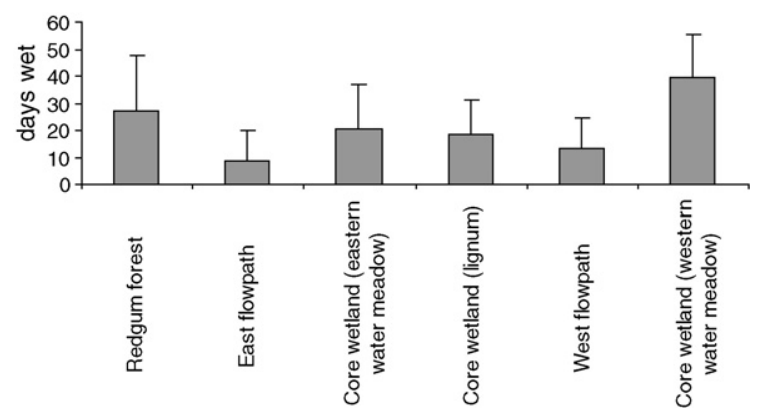

Fig. 5 - Mean and standard deviation of number of days pixels were inundated within spatial units for the 2004 flood event. Inundation is defined as open water surface of less than $11 \%$ reflectance in the mid-infrared band (AVHRR band $3 a)$.

predominantly wet pixels over the study area for the test flood event.

The results of the analysis of days wet indicate the core wetland areas remained wet in excess of 20 days (Fig. 4a). In addition they demonstrate that even at the $1 \mathrm{~km}$ resolution of the data, flooded areas, including major flood paths, and the duration of flooding can be determined. The time from inflow to flooding throughout the wetland was harder to discern, mainly due to the heavy rainfall and localised flooding which masked the movement of the flood front from inflows over the first few days. The first image after rainfall was removed from the analysis to provide a clearer indication of the movement of the flood peak. The results (Fig. 4b) clearly show the movement of the flood front over time.

The duration and standard deviation of open water flooding (Fig. 5) in flowpaths and core wetlands can be calculated for testing or calibration of the model.

\subsection{Discussion}

Density slicing of band 3a provided sufficient differentiation for the purpose of defining flooded areas, duration of flooding and time to peak for this flood event. Although Smith (1997) considered the use of visible and infrared satellite data to map open water bodies routine, a number of problems were found in this study to suggest otherwise for floodplains and wetlands. High turbidity may create difficulty in distinguishing flood areas from wet soil. Turbidity may have high spatial and temporal variability within a single flood as the suspended particles tend to drop out as the flood moves across the landscape. Turbidity may also vary between floods dependant on ground conditions at the time of flooding. The surrounding landscape can vary in many ways, from bare soil following drought to fallow conditions in cropping areas as well as different crop and wetland vegetation responses. Following flooding, emergent vegetation was likely to cover much of the water surface and it was therefore likely that this analysis underestimated the duration of flooding. Analysis of the vegetation response following inundation and the impact of mixed pixels on remote sensing analysis is being addressed in current research. McCarthy et al. (2003) found that the use of unsupervised classification provided the best differentiation between flood patterns over an inland wetland system using multi-temporal AVHRR datasets. Further development of the methodology is required to provide a robust approach that can be applied historically to build up a database of flood behaviour. However the results presented in this paper do demonstrate data can be acquired for model development from readily available, low-resolution satellite imagery.

\section{Model development}

\subsection{System conceptualisation}

The model was developed from first principles relating to water balance and system dynamics. Rather than adopting a predefined model, the Gwydir wetlands and floodplain can be broken into three components based on distinct hydrological or flooding characteristics, channels, flowpaths and core wetlands. Channels of a defined length and capacity flow through the floodplain. Once flow exceeds channel capacity, water spills over onto floodplain flowpaths. The flowpaths can be described as a set length, with width and depth (and therefore surface area) dependant on the volume of water contained within them. Water flows through the flowpath at a rate dependant on gradient, surface roughness and depth. In this system, gradient is very low and surface roughness can change dramatically from bare soil to $100 \%$ vegetation cover depending on moisture availability. A simpler approach has been used in this model which assumes that outflow from a flowpath is proportional to the volume of free surface water (i.e. an exponentially decaying store). The core wetland areas, such as water meadows and lignum swamps, are defined by a given area with depth and duration of inundation important model outputs. Outflows from flowpaths and core wetlands can return to the next channel component, or can be routed directly to other flowpaths and core wetlands (Fig. 6).

Each of these components was then subjected to the principles of the water balance. The volume of water held within the soil was also considered, particularly for the flowpath components, where soil moisture may be one of the important flood benefits for less frequently inundated vegetation types. The antecedent soil moisture conditions of the flowpaths and core wetlands are critical to modelling flood extent, depths and duration.

\subsection{Model structure}

\subsubsection{Channels}

Channels are used to represent formed creeks, rivers or constructed channels that have a fixed capacity (defined as bankfull discharge). Each channel component has a length and width that remains constant regardless of flow. Rainfall and evaporation over the surface area of the channel, and an allowance for deep drainage and bank wetting losses proportional to flow, are included in this model. The majority of the water enters the channel components as inflow from upstream channels, flowpaths and core wetland outflows. A constant loss can be applied to each channel component to 


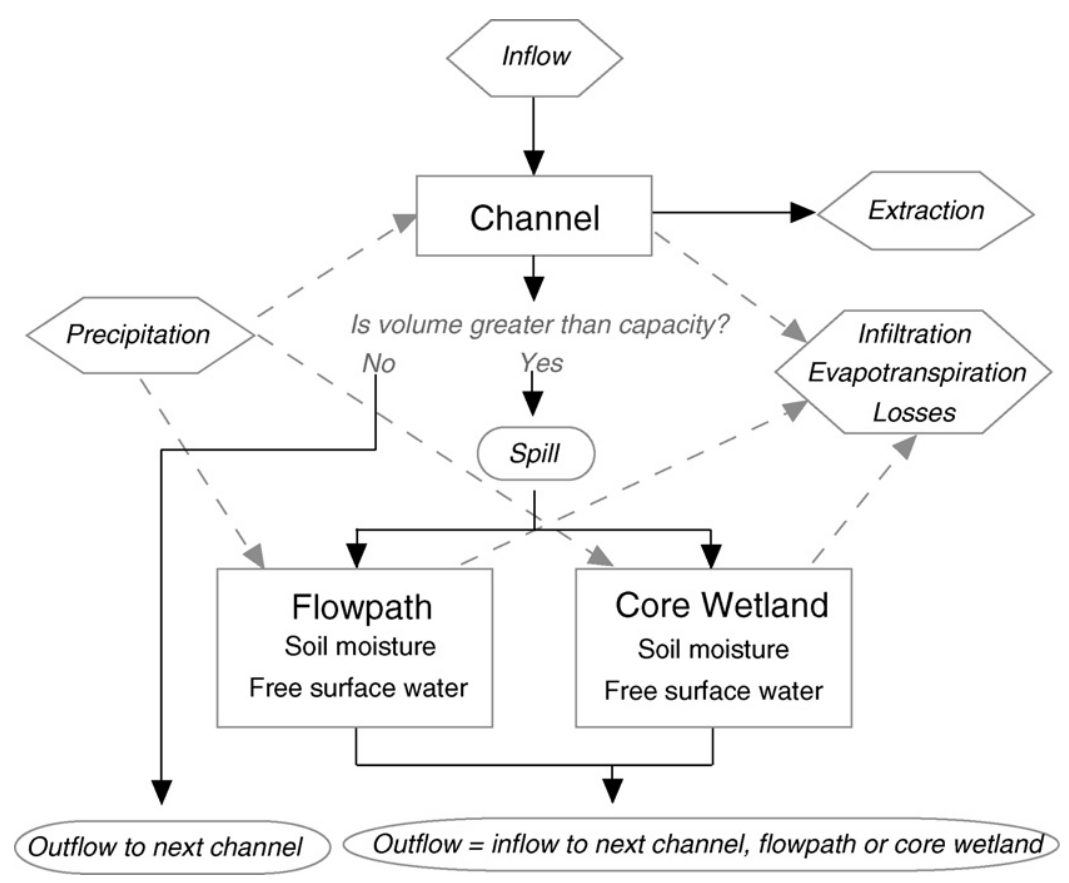

Fig. 6 - Conceptual flowchart of channels, flowpaths and core wetlands that can be used to create a semi-distributed model of a floodplain system.

allow for stock watering and general farm or household water use. Water in excess of channel capacity spills into flowpaths and core wetlands, while flow within channel capacity routes to the next channel component downstream.

\subsubsection{Flowpaths}

Once inflows to the wetland and floodplain system exceed channel capacity, water flows through preferential flowpaths. These flowpath components are determined from flood maps and satellite image interpretation. The average flowpath depth varies with the area inundated. By assuming a fixed length, and using existing data to determine the volume to surface area relationships, the overland flowpath component was simplified to a shallow inverted triangle, with a fixed depth/width ratio. Soil water and free water (standing water) are partitioned, as outflow is calculated as an exponential decay function of free water. While the exponentially decaying store may not be physically correct in all systems, this approach is commonly used to model discharge (Croke, 2006) and has been adapted here to approximate the water move- ment through the flowpaths in the model. The volume $\mathrm{V}$ held on day $t$ within a flowpath component is

$V_{t}= \begin{cases}V_{t-1}+I_{t}-O_{t}+R_{t} A_{\max }-\left(A_{t-1} E_{t-1} D_{t-1} / C\right)-c & \text { where } R_{t}>B \\ V_{t-1}+I_{t}-O_{t}+R_{t} A_{t}-\left(A_{t-1} E_{t-1} D_{t-1} / C\right)-c & \text { otherwise }\end{cases}$

where $I$ is inflow, $O$ is the outflow, $R$ is the rainfall, $A_{\max }$ is the maximum flowpath area and $A$ is the area affected by a flood event; $D$ is soil water depth over the area affected by the flood, $C$ is the field capacity of the soil, $E$ is the pan evaporation and $\mathrm{c}$ is a constant loss. As the volume is dependant on the area flooded at $t-1$, rainfall over the maximum flowpath area is calculated when the rainfall is greater than the soilwater deficit $B$ (the volume of water required to saturate the soil) to ensure volume includes heavy rainfall events capable of causing localised flooding. Otherwise it is only determined over the area affected by flooding.

Soil water depth is calculated over the flowpath area that has not been inundated by an event based on evapotranspiration and rainfall. Soil water is considered 'full' when at

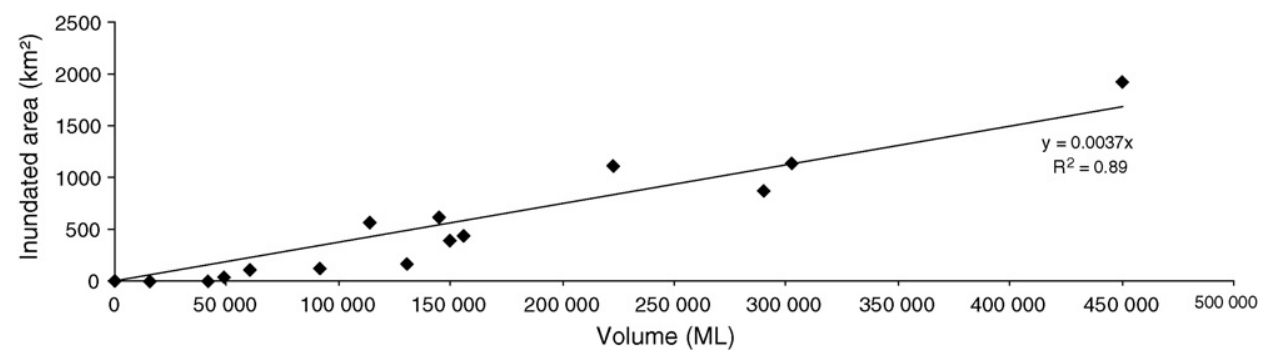

Fig. 7 - Initial volume to area inundated relationship for the entire Gwydir wetlands representing the maximum extent of flooding or response for all documented floods (maps and/ area estimates) (Department of Infrastructure, Planning and Natural Resources, unpublished data). 


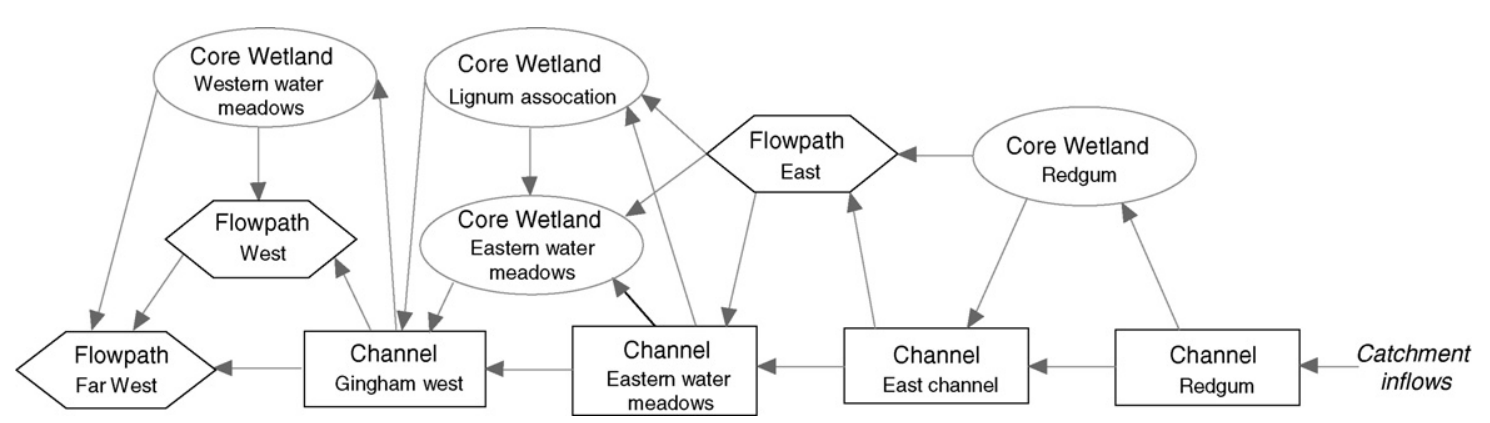

Fig. 8 - Simplified representation of core wetlands, flowpaths and channels of the Gwydir floodplain wetlands.

field capacity and 'empty' when at wilting point, therefore representing the volume of water available for plant growth. The soil water deficit for any given day can then be calculated over a given area. This involves a two-step calculation where inundated area is first estimated from a general volume/area function determined using existing data (Fig. 7). However some of the water volume will be used to fill the soil water deficit, leaving a smaller volume to inundate an area. The soil water deficit is therefore calculated over that estimated area (if the soil water depth is less than the maximum soil water store) and subtracted from the volume. The final inundated area is then recalculated on the remaining free water component of the volume.

If the flowpath is flooded then soil water depth over the affected area A should generally be saturated. However if this area is decreasing over time, then the average soil water depth will also decrease below saturation as an average over the affected area. The average soil water depth $D$ over the floodaffected area during flooding is simply the soil water volume divided by the actual flooded area. If there is no longer inundation (free water), then the average soil water over the affected area $D$ is

$D_{t}=\frac{D_{t-1}-E_{t-1} D_{t-1}}{C+R_{t}}$

Until such time as the average soil water depth over the area affected, and the soil water depth over areas not affected by flooding are equal, a flood event still has some benefits to veg- etation and a broader area is considered affected by the flood event.

\subsubsection{Core wetlands}

Each core wetland is a defined vegetation assemblage covering a set area. The important outputs from the core wetland model are the average depth of inundation and the duration of inundation. Similar to the flowpath model, the volume of water within the core wetland component is partitioned into soil water and free water.

When the volume exceeds the area times the soil water capacity, soil water is set at the maximum soil water depth (field capacity of the soil) and the remaining volume is defined as free water. Outflow occurs once free water exceeds a given threshold. When free water exceeds a maximum volume, all excess water is routed immediately to the next component, otherwise outflow occurs at a given rate of free water volume.

The model components are combined to provide a simplified representation of the study area (Fig. 8). In this diagram, the east to west orientation of the Gwydir floodplains is retained. The far-west flowpath representing the maximum probably flood has not been parameterised pending evaluation of a very large flood event.

\subsection{Model parameterisation}

The length of each channel component was measured from topographic maps, while average bankfull discharge (the

Table 1 - Initial parameterisation of the channel reaches

\begin{tabular}{lllll} 
& Redgum channel & East channel & EWM channel & Western channel \\
\hline $\begin{array}{l}\text { Bankfull discharge } \\
\text { (ML/day) }\end{array}$ & 20000 & 15000 & 4000 & 2000 \\
Loss factor & & & & \\
Inflow 1 & 0.05 & 0.05 & 0.05 & 0.05 \\
& User input & $100 \%$ redgum & $100 \%$ east channel & $100 \%$ lignum core \\
Inflow 2 & $(418004$ gauge) & channel outflow & outflow & wetland outflow \\
& n/a & $75 \%$ redgum forest & $50 \%$ east flowpath & $100 \%$ EWM channel \\
Inflow 3 & n/a & outflow & outflow & $25 \%$ EWM core \\
& & n/a & n/a & wetland outflow \\
Length (km) & 18 & 55 & 40 & 50 \\
Width (m) & 10 & 10 & 3 & 2 \\
Constant (loss) & 1000 & 100 & 100 & 200 \\
\hline a Eastern Water Meadow. & & & \\
\hline
\end{tabular}


Table 2 - Initial parameterisation of the flowpath components.

\begin{tabular}{lll} 
& \multicolumn{1}{c}{ Eastern flowpaths } & Western flowpaths \\
\hline Outflow factor & 0.7 & 0.5 \\
Field capacity $(\mathrm{mm})$ & 250 & 250 \\
Inflow 1 & $100 \%$ eastern channel spill & $100 \%$ western channel outflow \\
Inflow 2 & $25 \%$ redgum forest outflow & $100 \%$ WwM \\
Inflow 3 & $\mathrm{n} / \mathrm{a}$ & $25 \%$ western channetland outflow \\
Length $(\mathrm{km})$ & 55 & 60 \\
Constant (loss) (ML/day) & 0 & 0 \\
Maximum area (km $\left.{ }^{2}\right)$ & 200 & 150 \\
Threshold (ML) & 100 & 1000 \\
\hline
\end{tabular}

${ }^{a}$ Western Water Meadow.

maximum channel flow within channel banks) and channel widths are estimated from gauging station details and local knowledge. The initial development of the model combines the Gwydir and Gingham systems due to insufficient information on flow separation to the two channels and parameters. Inflows define the connections of the model. The channel components also include two loss functions that are estimated. The loss factor is the estimated proportion of flow that is lost to the stream from stream bank wetting and soil infiltration. A constant loss can also be applied to account for stock watering and domestic and general farm use (Table 1).

Two flowpaths are defined for initial model development and testing (Table 2), with the Gingham and Gwydir systems combined into eastern flowpaths and western flowpaths. Input parameters include the field capacity of the typical soils of the area (assuming an effective root depth for the vegetation of interest of $1 \mathrm{~m}$ ), length determined from topographic maps and the maximum area of inundation from mapped flood events. Estimated parameters include an outflow factor which defines the proportion of volume that exits the flowpath and was estimated satellite image interpretation which indicates that the flows slow and widen from east to west due to slope and roughness factors.

Core wetland areas are defined from vegetation mapping (McCosker, 1994) while the maximum depth (above which all inflow is outflow) and minimum depth (below which no outflow occurs) are determined from published and unpublished data from the integrated monitoring of environmental flows (Chessman, 2003; Mawhinney, 2003) (Table 3). The outflow factor was estimated and used as a calibration factor in the model.

\subsection{Model evaluation}

The model outputs are considered in relation to a set of key criteria identified for ecological benefit:

- the depth of flooding,

- the duration of flooding,

- the area inundated by a flood event, and

- the soil moisture for floodplains and wetlands to assess drying and parching.

Model errors are presented where observed data were available for comparison. A commonly used numerical error estimation is the mean square error (MSE) or the root of the mean square error (RMSE):

$\mathrm{MSE}=\frac{1}{n} \sum_{t=1}^{n}\left(o_{t}-m_{t}\right)^{2}$

$\mathrm{RMSE}=\sqrt{\mathrm{MSE}}$

where $o_{t}$ is the observed value at time $t$ and $m_{t}$ is the modelled value.

To enable comparison of RMSE values across different variables or across events of different magnitude, RMSE can be

Table 3 - Initial parameterisation of the core wetland components

\begin{tabular}{lllll} 
& \multicolumn{1}{c}{ Redgum } & & LWignum & WWM \\
\hline Area $\left(\mathrm{km}^{2}\right)$ & 27 & 93 & 27 & 30 \\
Outflow factor & 0.2 & 0.2 & 0.2 & 0.2 \\
Maximum depth $(\mathrm{mm})$ & 300 & 500 & 500 & 500 \\
Field capacity $(\mathrm{mm})$ & 250 & 250 & 250 & 250 \\
Inflow 1 & $100 \%$ redgum channel & $75 \%$ EWM channel & $75 \%$ EWM core & $75 \%$ western channel \\
& spill & spill & wetland outflow & spill \\
Inflow 2 & n/a & 25\% eastern & $25 \%$ eastern flowpath & outflow \\
& n/a & flowpath outflow & $25 \%$ EWM channel & n/a \\
Inflow 3 & n/a & spill & 200 & 200
\end{tabular}

\footnotetext{
a Eastern Water Meadow.
}

b Western Water Meadow. 


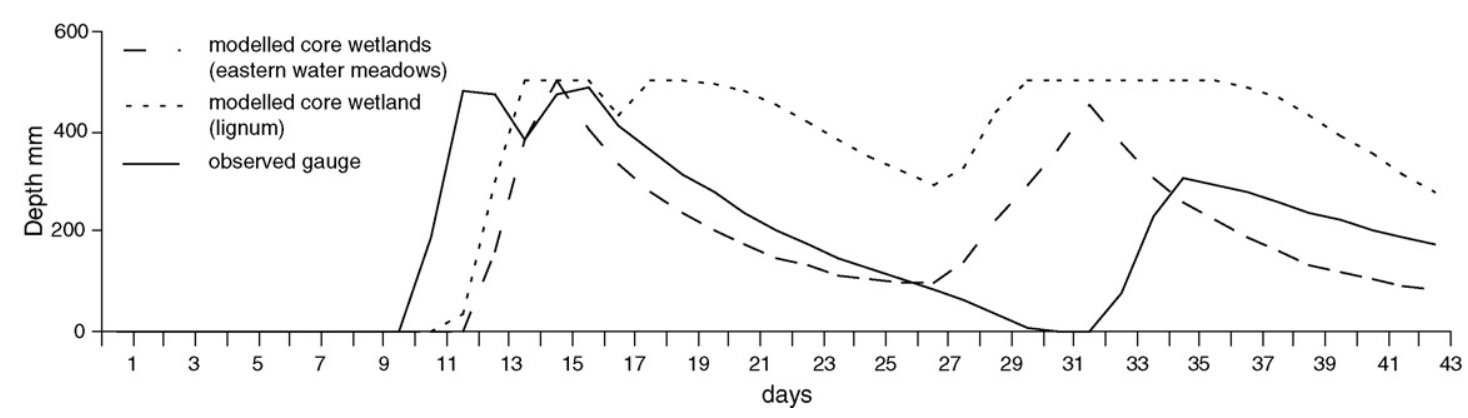

Fig. 9 - Comparison of observed gauge (418083) and modelled depth of inundation within core wetlands of lignum (RMSE $230 \mathrm{~mm}, \mathrm{RMSE}_{\mathrm{r}} 1.31 \mathrm{~mm}$ ) and eastern water meadows (RMSE $155 \mathrm{~mm}, \mathrm{RMSE}_{\mathrm{r}} 0.89 \mathrm{~mm}$ ).

normalised as

$\operatorname{RMSE}_{\mathrm{r}}=\frac{\sqrt{\mathrm{MSE}}}{\overline{0}}$

where $\bar{o}$ is the mean of the observed values. For both RMSE and $\mathrm{RMSE}_{\mathrm{r}}$ smaller values indicate small errors showing that the modelled values match the observed values well (Pebesma et al., 2005).

\subsection{Model results}

The modelled depths for the lignum and eastern water meadow core wetlands are compared to the Gingham Channel at Rookery gauge height (Fig. 9). The time-series comparison demonstrates that the model can simulate depths to within $100 \mathrm{~mm}$ of the observed data in the eastern water meadows with similar rates of recession RMSE $_{\mathrm{r}}$ of 1.31 and 0.89 , respectively). Analysis of the cumulative depths during the event showed lower errors for both lignum and eastern water meadows (RMSE $E_{\mathrm{r}}$ of 0.81 and 0.25 , respectively) compared to the daily depths indicating that timing errors accounted for a significant portion of the errors.

The modelled flood dynamics for the eastern flowpath (Fig. 10) show a peak in the area inundated and inundation depths for days 13 and 14, and a secondary peak on day 31. The soil water depth within the areas inundated by the inflows remained near saturation until day 38 , while areas only receiving direct rainfall never reached saturation.

As there are currently no gauges or soil moisture probes located on the floodplain, satellite interpretation of the event was used to examine the accuracy of the model outputs. The analysis indicates that the pixels within the eastern flowpath remained wet (free surface water) for a mean of 9 days with a standard deviation of 11 days (Fig. 5). The modelled data (Fig. 10) suggests that some areas of the flowpath remained wet for up to 23 days (soil at saturation). Examining both the modelled area inundated and the modelled inundation depth shows that most of the flowpath that was inundated only remained wet for 5 days in the first peak and 4 days in the second peak, showing a similar pattern to that observed from the satellite image interpretation.

The model was then run over a longer time sequence, using daily inflow data from the Gwydir River at Yarraman gauge and rainfall and evapotranspiration data from the Moree Bureau of Meteorology (BoM) station.

The modelled depth within the lignum and eastern water meadows was compared to the observed gauge at the Rookery (Fig. 11) for the period August 2000-2003. Observed gauge records are discontinuous due to equipment failure as indicated by the broken line. Results showed that the model most of the flood events with peak depth and duration similar to the observed data. The 2003 peak was not well represented and was of interest as the observed gauge pattern was markedly different from previous peaks. Discussions with local landowners indicated that the adjacent channel had been dredged prior to this event in response to some sedimentation of the channel. This was done to allow for better flows through the system to replenish farm dams and stock water supplies further west in a period of drought. This would change the volumes of water spilling into the adjacent model components, in this case the core wetland, as indicated by the gauged data.

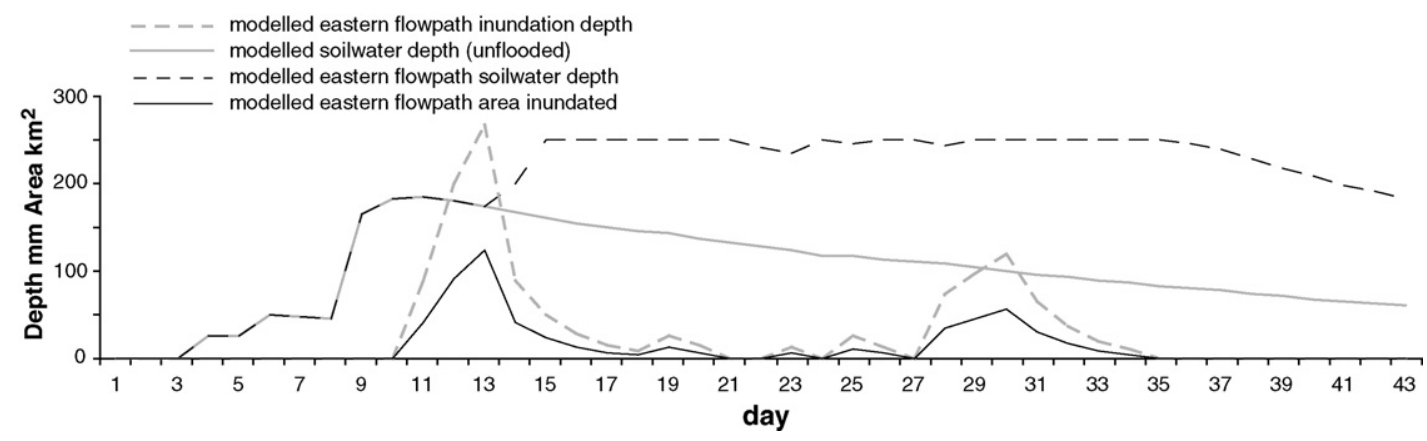

Fig. 10 - Modelled flood dynamics of eastern flowpath 2004/2005. 


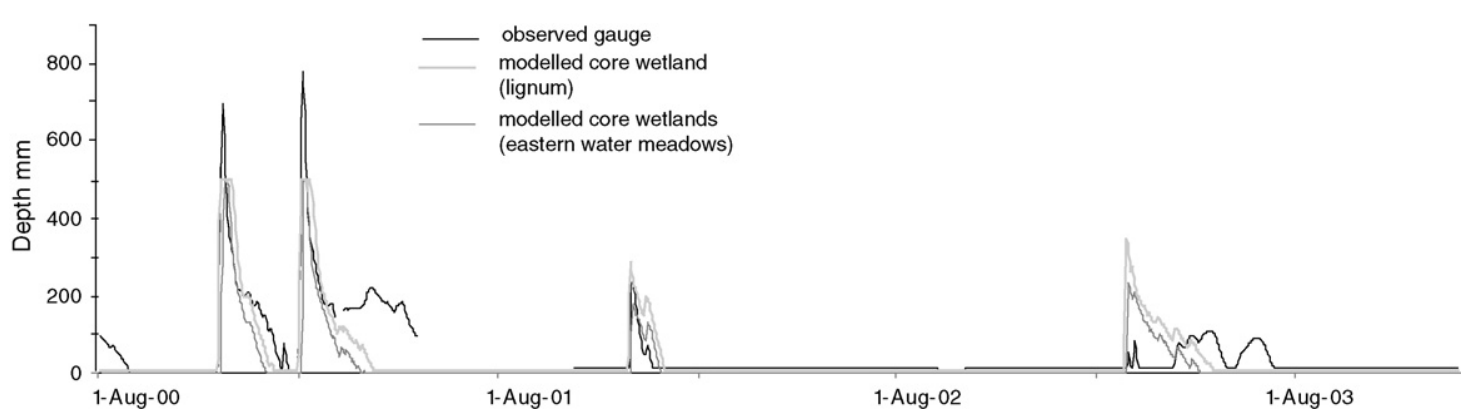

Fig. 11 - Time series of modelled depth in eastern water meadow and lignum core wetlands and observed gauge height at Gingham Channel at Rookery. Note the discontinuous height recording at the Rookery due to instrument malfunction.

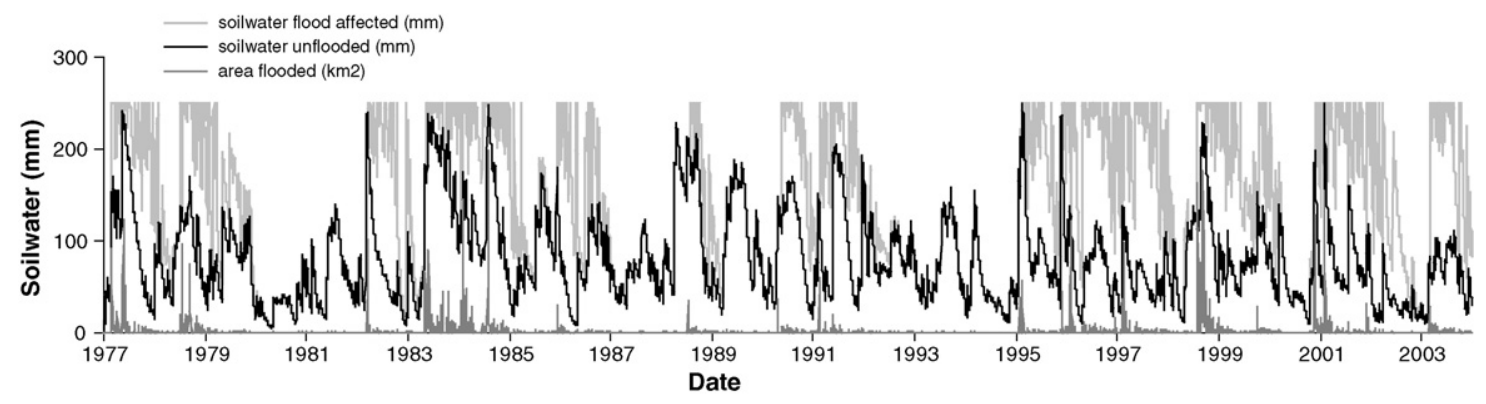

Fig. 12 - Modelled flood dynamics and soil moisture status of the eastern flowpaths 1977-2003.

The flood dynamics of the eastern flowpath was also run over a 26-year period from 1977 to 2003. Although there are no observed datasets to test the model outputs, the modelled soil moisture under areas influenced by flooding compared to areas over the broader floodplain not influenced by a flood event are consistent with expectations (Fig. 12). This demonstrates the application of the model towards understanding of the wet/dry cycles of the system and clearly shows the periods where there was no benefit from flooding. Further remote sensing analysis of vegetation condition may provide data to test the model outputs in the future.

\section{Conclusions}

This paper outlines the development of a parsimonious model for assessing ecologically significant flood dynamics of floodplain wetlands. Although much is understood of floodplain wetlands, there is a paucity of available data to develop and calibrate models using conventional modelling approaches. Low-spatial and high-temporal resolution satellite imagery such as AVHRR can be used to distinguish major flowpaths and provide data on the duration of flooding and time to peak at a level useful to model development and calibration.

A model developed with limited data and at low-cost was tested under a range of climatic conditions. Results demonstrate that the model can simulate the ecologically significant dynamics of the floodplain wetland through a single event and over long climatic sequences. Depth and duration of flooding for defined core wetland areas were well represented in comparison to observed and expected behaviour. The dura- tion of flooding over flowpaths can be simulated within days of observed remotely sensed data. The capacity to simulate broader floodplain and flowpath flood and soil moisture dynamics through both wet and dry cycles provides the ability to objectively assess wetland condition in the context of water allocations and environmental flow allocations. This new insight into the impact of drought, water extractions and water diversions on floodplains can benefit the development of a decision support system for environmental flows to floodplain wetland systems.

Further development of the model including better spatial representation of the system, development of the soil moisture balance and further data acquisition of a range of historical floods using remote sensing can provide the basis for a objective decision support system for wetland water management in the Gwyder catchment. A project is currently underway to address these issues and to integrate vegetation response dynamics into the model.

\section{Acknowledgements}

Sue Powell would like to acknowledge the Integrated Catchment Assessment and Management Centre (iCAM) at The Australian National University for partly funding this research through a Masters scholarship. The authors would like to thank comments from two anonymous reviewers which improved our paper. PhD funding through The Australian National University, CSIRO Water for a Healthy Country and the Cotton Catchments Communities Co-operative Research Centre are allowing for the further development of this research. 


\section{REF E R E N C E S}

Allan, A., Lovett, S., 1997. Impediments to Managing Environmental Water Provisions. Bureau of Resource Sciences, Canberra.

Barton, I.J., Bathols, J.M., 1989. Monitoring floods with AVHRR. Remote Sens. Environ. 30, 89-94.

Bennett, M., McCosker, R., 1994. Estimating environmental flow requirements of wetlands. In: Proceedings of the Environmental Flows Seminar, AWWA, Artarmon, pp. 9-16.

Brock, M.A., Casanova, M.T., 1997. Plant life at the edges of wetlands; ecological responses to wetting and drying patterns. In: Klomp, N., Lunt, I. (Eds.), Frontiers in Ecology: Building the Links. Elsevier Science, Oxford, pp. 181-192.

Bureau of Meteorology, 2004. Moree NSW: Daily Weather Observations, Accessed: December 2004-February 2005. 2004/2005

Casanova, M.T., Brock, M.A., 2000. How do depth, duration and frequency of flooding influence the establishment of wetland plant communities? Plant Ecol. 147, 237-250.

Chauhan, M., Gopal, B., 2005. Vegetation structure and dynamics of a floodplain wetland along a subtropical regulated river. River Res. Appl. 21, 513-534.

Chessman, B.E., 2003. Integrated Monitoring of Environmental Flows: State Summary Report 1998-2000. Department of Infrastructure, Planning and Natural Resources, Sydney.

Chessman, B., Jones, H., 2001. Integrated Monitoring of Environmental Flows: Design Report. Department of Land and Water Conservation, Parramatta.

Costelloe, J.F., Grayson, R.B., Argent, R.M., McMahon, T.A., 2003. Modelling the flow regime of an arid zone floodplain river, Diamantina River, Australia. Environ. Model. Softw. 18 693-703.

Croke, B.F.W., 2006. A technique for deriving an average event unit hydrograph from streamflow-only data for ephemeral quick-flow-dominant catchments. Adv. Water Resour. 29, 493-502.

Department of Environment and Conservation, 2003. New South Wales State of the Environment 2003. Department of Environment and Conservation, Sydney.

Department of Infrastructure Planning and Natural Resources, 2004. Draft Exhibition Document: Lower Gingham Watercourse Floodplain Management Plan V1. 4. Department of Infrastructure Planning and Natural Resources, Tamworth.

Environment Australia, 2001. A Directory of Important Wetlands in Australia, 3rd ed. Environment Australia, Canberra.

Faulkenmire, A., 2004. Flood Volumes, Duration and Areas in the Gwydir Wetlands. Unpublished data from the Department of Infrastructure, Planning and Natural Resources Flood Studies.

Ferrati, R., Canziani, G.A., 2005. An analysis of water level dynamics in Esteros del Ibera wetland. Ecol. Model. 186, 17-27.

Frazier, P.S., Page, K.L., 2000. Water body detection and delineation with landsat TM data. Photogramm. Eng. Remote Sens. 66, 1461-1465.

Geoscience Australia, 2005. ACRES NOAA-AVHRR Online Data. Australian Government, Accessed: Downloaded December 5, 2004-February 20, 2005. 2004-2005.

Keyte, P., 1994. Lower Gwydir Wetland Plan of Management 1994 to 1997. Report by NSW Department of Water Resources for the Lower Gwydir Wetland Steering Committee, NSW Department of Water Resources, Sydney.

Kingsford, R.T., 2000. Ecological impacts of dams, water diversions and river management on floodplain wetlands in Australia. Austr. Ecol. 25, 109-127.

Kingsford, R.T., Auld, K.M., 2005. Waterbird breeding and environmental flow management in the Macquarie Marshes, Arid Australia. River Res. Appl. 21, 187-200.
Kingsford, R.T., Johnson, W., 1998. Impact of water diversions on colonially nesting waterbirds in the Macquarie Marshes of Arid Australia. Colon. Waterbird 21, 159-170.

Kingsford, R.T., Thomas, R.F., 2002. Use of satellite image analysis to track wetland loss on the Murrumbidgee River floodplain in arid Australia, 1975-1998. Water Sci. Technol. 45, 45-53.

Letcher, R.A., Jakeman, A.J., Croke, B.F.W., 2004. Model development for integrated assessment of water allocation options. Water Resour. Res. 40, W05502, doi:10.1029/2003WR002933.

Mawhinney, W., 2003. Restoring biodiversity in the Gwydir wetlands through environmental flows. Water Sci. Technol. $48,73-81$.

McCarthy, J., 2002. Remote sensing for detection of landscape form and function of the Okavango Delta Botswana. Dissertation Thesis. Royal Institute of Technology, Stockholm, $49 \mathrm{pp}$.

McCarthy, J., Gumbricht, T., McCarthy, T.S., Frost, P., Wessels, K., Seidel, F., 2003. Flooding patterns of the Okavango wetland in Botswana between 1972 and 2000. Ambio 32, 453-457.

McCarthy, J., Gumbricht, T., McCarthy, T.S., 2005. Ecoregion classification in the Okavango Delta, Botswana from multitemporal remote sensing. Int. J. Remote Sens. 26, 4339-4357.

McCosker, R., 1994. The preparation of a plan of management for the Gingham Watercourse. Master's Thesis. University of New England, Armidale.

McCosker, R., 1996. Gwydir Wetlands Ecological Response to Flooding. 1995-1996. LANDMAX Natural Resource Management Services.

McCosker, R., 1999. Gwydir Wetlands Ecological Response to Flooding. 1997. LANDMAX Natural Resource Management Services.

McCosker, R., 2001a. Gwydir Wetlands Ecological Response to Flooding. 1998. LANDMAX Natural Resource Management Services.

McCosker, R., 2001b. Gwydir Wetlands Ecological Response to Flooding. 2000-2001. LANDMAX Natural Resource Management Services.

Mertes, L.A.K., 2002. Remote sensing of riverine landscapes. Freshwater Biol. 47, 799-816.

Mohamed, Y.A., Bastiaanssen, W.G.M., Savenije, H.H.G., 2004. Spatial variability of evaporation and moisture storage in the swamps of the upper Nile studied by remote sensing techniques. J. Hydrol. 289, 145-164.

Overton, I.C., 2005. Modelling floodplain inundation on a regulated river: integrating GIS, remote sensing and hydrological models. River Res. Appl. 21, 991-1001.

Pebesma, E.J., Switzer, P., Loague, K., 2005. Error analysis for the evaluation of model performance: rainfall-runoff event time series data. Hydrol. Process. 19, 1529-1548.

Phinn, S.R., 1998. A framework for selecting appropriate remotely sensed data dimensions for environmental monitoring and management. Int. J. Remote Sens. 19, 3457-3463.

Podger, G., Hameed, T., 2000. Use of IQQM to develop environmental flow rules for the Lachlan regulated river system, Hydro 2000. In: Proceedings of the 3rd International Hydrology and Water Resources Symposium, Perth, WA, Australia.

Roberts, J., Marston, F., 2000. Water Regime of Wetland and Floodplain Plants in the Murray-Darling Basin: A Source Book of Ecological Knowledge. CSIRO Land and Water, Canberra.

Roberts, J., Young, B., Marston, F., 2000. Estimating the water requirements for plants of floodplain wetlands: a guide. Occasional Paper 04/00. Land and Water Resources Research and Development Corporation, Canberra.

Roshier, D.A., Rumbachs, R.M., 2004. Broad-scale mapping of temporary wetlands in arid Australia. J. Arid Environ. 56, 249-263. 
Sanchez-Carrillo, S., Angeler, D.G., Sanchez-Andres, R., Alvarez-Cobelas, M., Garatuza-Payan, J., 2004.

Evapotranspiration in semi-arid wetlands: relationships between inundation and the macrophyte-cover:open-water ratio. Adv. Water Resour. 27, 643-655.

Sheng, Y., Gong, P., Xiao, Q., 2001. Quantitative dynamic flood monitoring with NOAA AVHRR. Int. J. Remote Sens. 22, 1709-1724.

Simons, M., Podger, G., Cooke, R., 1996. IQQM-a hydrologic modelling tool for water resource and salinity management. Environ. Softw. 11, 185-192.

Smith, L.C., 1997. Satellite remote sensing of river inundation area, stage, and discharge: a review. Hydrol. Process. 11, 1427-1439.

Thompson, J.R., Sorenson, H.R., Gavin, H., Refsgaard, A., 2004. Application of the coupled MIKE SHE/MIKE 11 modelling system to a lowland wet grassland in southeast England. J. Hydrol. 293, 151-179.
Turner, P., Davies, H., 1998. Common AVHRR Processing Software (CAPS). In: Proceedings of the Land AVHRR Workshop, 9th Australasian Remote Sensing and Photogrammetry Conference, Sydney.

Verdin, J.P., 1996. Remote sensing of ephemeral water bodies in western Niger. Int. J. Remote Sens. 17, 733-748.

Whigham, P.A., Young, W.J., 2001. Modelling river and floodplain interactions for ecological response. Math. Comput. Model. 33, 635-647.

Young, W.J., Scott, A.C., Cuddy, S.M., Rennie, B.A., 2003. Murray flow assessment tool-a technical description. Client Report, 2003. CSIRO Land and Water, Canberra.

Zhang, L., Mitsch, W.J., 2005. Modelling hydrological processes in created freshwater wetlands: an integrated system approach. Environ. Model. Softw. 20, 935-946. 